PERM JOURNAL OF PETROLEUM AND MINING ENGINEERING

ВЕСТНИК ПНИПУ. ГЕОЛОГИЯ. НЕФТЕГАЗОВОЕ И ГОРНОЕ ДЕЛО

ISSN 2224-9923

Volume / Tом 20 №2, 2020

http://vestnik.pstu.ru/geo/

UDC $622 / 276+550.834(252.6)$

Article / Статья

(C) PNRPU / ПНИПУ, 2020

\title{
OBTAINING HIGH-QUALITY SEISMIC DATA IN THE NORTHERN PERM KRAI SWAMPY AREAS
}

\author{
lurii M. Zakharov, Ivan S. Putilov
}

PermNIPIneft branch of LUKOIL-Engineering LLC in Perm (3a Permskaya st., Perm, 614015, Russian Federation)

\section{ПОЛУЧЕНИЕ КАЧЕСТВЕННЫХ СЕЙСМИЧЕСКИХ ДАННЫХ НА ЗАБОЛОЧЕННЫХ ТЕРРИТОРИЯХ СЕВЕРА ПЕРМСКОГО КРАЯ}

\section{Ю.М. Захаров, И.С. Путилов}

Филиал ООО «ЛУКОЙЛ-Инжиниринг» «ПермНИПИнефть» в г. Перми (614015, Россия, г. Пермь, ул. Пермская, 3a)

Received / Получена: 14.02.2020. Accepted / Принята: 15.04.2020. Published / Опубликована: 15.06.2020

Key words:

seismic exploration, processing, interpretation, excitation source, seismic receiver, seismogram, blast well, swampy areas, Geoton, GS-ONE, GS-20 DX.

\begin{abstract}
The study undertakes to solve the problem of obtaining reliable seismic data in swampy areas. Raw hydrocarbon deposits in the North of Perm Krai are a promising asset, but their geological survey is constrained due to problematic surface conditions. Seismic exploration is the most detailed and reliable remote method of geological subsurface studies, but any state-of-the-art seismic 3D survey requires covering a much larger surface area than an actual area of a targeted subsurface survey. Swamps tend to strongly attenuate seismic waves, thus complicate a further geological interpretation of obtained data, and significantly limit the choice of engineering tools and techniques of surveying. Also it is impossible to avoid the influence of hard surface conditions in territories extending over hundreds of square kilometers. In order to explore the possibility of obtaining high-quality data in such conditions, we offer a comprehensive pilot survey using various recording and seismic wave excitation facilities. We analyzed and explored the possibility of solving this problem by using advanced seismic exploration methods. The study looks into the technology of obtaining primary data and into the stage of information processing for its further geological interpretation. This is the first time that Geoton seismic pulse source and GS$O N E$ high-sensitivity seismic receivers have been used for these purposes. According to the findings, there is an obvious advantage of using the blast over pulse source, especially in the swamp bed itself. At the same time, Geoton proved to be highly eco-friendly and safe, which makes it possible to use it in seismic exploration works of inhabited areas. The results of processing the pilot survey data show that the single seismic receivers produce wave patterns with the best quality and accuracy. The paper offers the seismic exploration techniques in swampy conditions and in territories that have increased requirements to environmental protection and safety.
\end{abstract}

Ключевые слова: сейсморазведка, обработка, интерпретация, источник возбуждения, сейсмоприемник, сейсмограмма, взрывная скважина, заболоченные территории, обработка, Геотон, GS-ONE, GS-20 DX.

\begin{abstract}
Рассматривается проблема получения достоверных сейсмических данных на заболоченных участках Месторождения углеводородного сырья северных территорий Пермского края являются весьма перспективными активами, но достаточно сложны для геологического изучения, так как расположены в сложных поверхностных условиях. Сейсморазведка является наиболее детальным и достоверным дистанционным методом геологического изучения недр, но современные сейсмические 3D-съемки требуют покрывать сетью профилей значительно большую территорию на поверхности, чем занимает сам объект поиска в глубине. Заболоченные участки не только существенно ослабляют сейсмические волны, что приводит к получению сложных для дальнейшей геологической интерпретации данных, но и накладывают существенные ограничения на технические и методические аспекты изучения, а избежать влияния сложных поверхностных условий на территории площадью в сотни квадратных километров невозможно. С целью оценки возможностей получения качественных данных в подобных условиях были проведены расширенные опытные работы с применением различных типов регистрирующего и возбуждающего сейсмические волны оборудования. Представлен анализ и дана оценка возможности решения данной проблемы при помощи современных методик в области сейсморазведки. Исследование затронуло технологию получения первичных данных и этап обработки информации с целью ее дальнейшей геологической интерпретации. Рассмотрены такие новшества, как импульсный источник сейсмических колебаний «Геотон» и высокочувствительные сейсмоприемники «GS-ONE». В результате сделаны выводы о некотором преимуществе взрывного источника над импульсным, особенно непосредственно на толще болота, но одновременно отмечена высокая экологичность и безопасность источника «Геотон», что формирует возможность его широкого применения при сейсморазведочных работах в населенных пунктах. По результатам обработки данных опытных работ отмечено лучшее качество и детальность волновой картины, зарегистрированной одиночными сейсмоприемниками.

В результате осушествленной работы выданы методические рекомендации для проведения сейсморазведочных работ в условиях заболоченности и на территориях с повышенными требованиями к экологичности и безопасности.
\end{abstract}

Iurii M. Zakharov - Lead Geophysicist of the Center for Seismic Research (tel.: +007 95233269 42, e-mail: Zaxarov_U@mail.ru). The contact person for correspondence. Ivan S. Putilov (Scopus ID 25723777700) - Doctor of Engineering, Deputy Director of the Branch for Scientific Work in the Field of Geology (tel.: +007 34236458 , e-mail: Ivan.Putilov@pnn.lukoil.com).

Захаров Юрий Михайлович - ведущий геофизик центра сейсмических исследований (тел.: +007 95233269 42, e-mail: Zaxarov_U@mail.ru). Контактное лицо для переписки Путилов Иван Сергеевич - доктор технических наук, заместитель директора филиала по научной работе в области геологии (тел.: +007 34236458 , e-mail: Ivan.Putilov@pnn.lukoil.com). 


\section{Introduction}

Obtaining reliable seismic data in seismically restrained swampy areas is somewhat problematic. Behavior of deformation waves in inhomogeneous media has always been in the focus of studies of geophysics, geologists and even builders [1, 2]. Their interest is associated with the fact that the anomalies caused by the influence of these media can have a substantial effect on the wave pattern in the target survey intervals. Now specialists note that the survey focus lies in small-size and low-amplitude targets, while the confounding factor of near-surface section (NSS) anomalies can change or completely hide such a target [3].

Apparently, multiple methods for factoring in the NSS anomalies exist and are actively used [4-8]. However, according to the author's personal findings accumulated over the past 10 years of work with the seismic exploration data in various Russian territories, some of the anomalies can be so powerful that it appears to be impossible to factor them at the processing stage. Therefore, it is advisable to minimize them at the stage of obtaining primary data, i.e. during field seismic exploration works [9].

The problem of concern is highly relevant for the territory of Perm Krai, since the main bulk of seismic exploration works is performed using compact drilling rigs that are incapable of drilling blast wells deeper than $10 \mathrm{~m}$, which excludes the influence of a swampy bed on a seismic signal generation. Apart from the signal attenuation, suboptimal conditions of excitations produce intense waves, i.e. noise events, where Rayleigh waves and ringing pulses [10] are the most impactful. It is not possible to use more powerful machinery, as it violates the regionally adopted environmental protection standards [11], which forbid cutting down trees.

\section{Materials, Research Methods and Analysis of Results}

In order to analyze the possibility of improving the quality of the material obtained in the restrained surface and geological conditions, a pilot survey was made in Privolzhsky Federal Okrug, in the territory of Krasnovishersk District, the Northern part of Perm Krai. The 2D common depth point method profile entered the swamp (adverse surface conditions), forested area and the river Vilva flood plain. Such a diversity of surface conditions enabled obtaining the necessary wide range of data for the analysis.

The surveyed site is located in a zone highly unfavorable for seismic and geological works, characterized by pronounced wave field distortions, seismic energy absorption and dissipation, and high level of intense noise waves [12]. The effectiveness of the seismic exploration works deteriorates due to an over three-meter-thick peat bed covering the ground surface (which dampens seismic energy and causes reoccurring low-frequency vibrations), argillaceous-marl bed and Solikamsk horizon limestones. Such mechanical characteristics greatly influence generation of elastic waves [13]. Fig. 1 shows NSS velocity-depth model with lithology columns, demonstrating the surface and subsurface conditions of the test profile's location. The near-surface section throughout the profile is expressly inhomogeneous; the selected area has widely diverse surface and subsurface conditions, which corresponds to the objectives of the pilot production works.

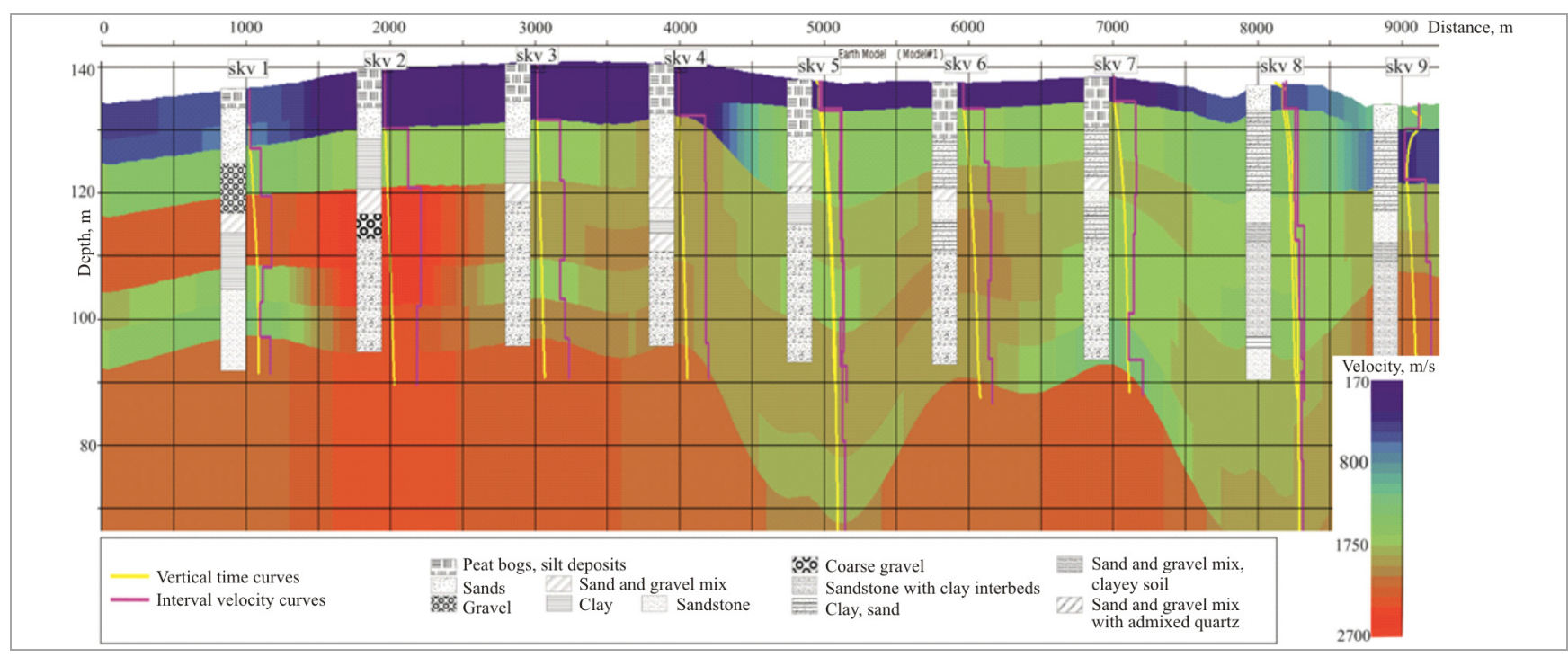

Fig. 1. NSS velocity-depth model 


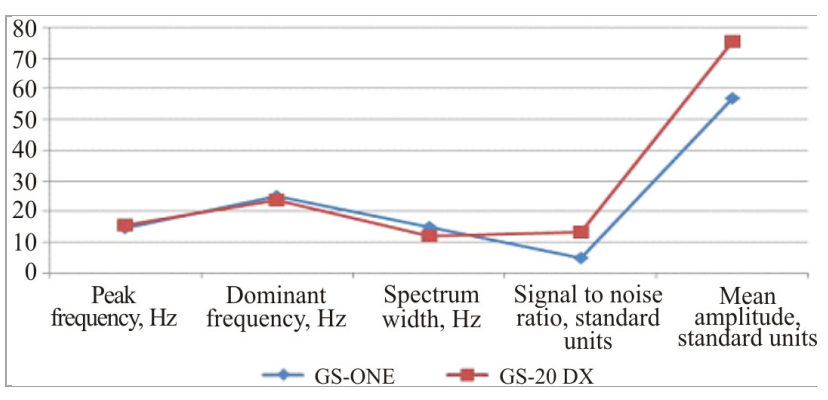

Fig. 2. Amplitude-frequency curves in GS-ONE seismic receivers and $G S-20 D X$ geophone groups

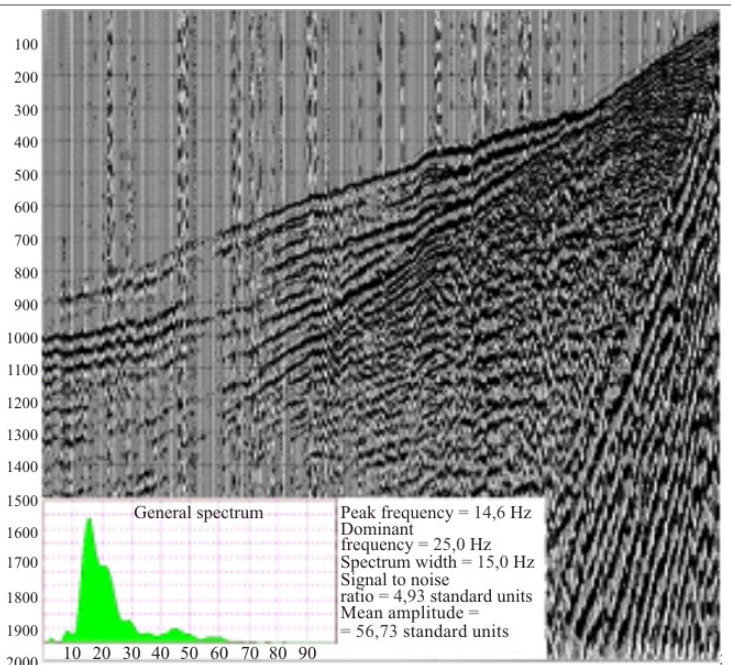

$a$

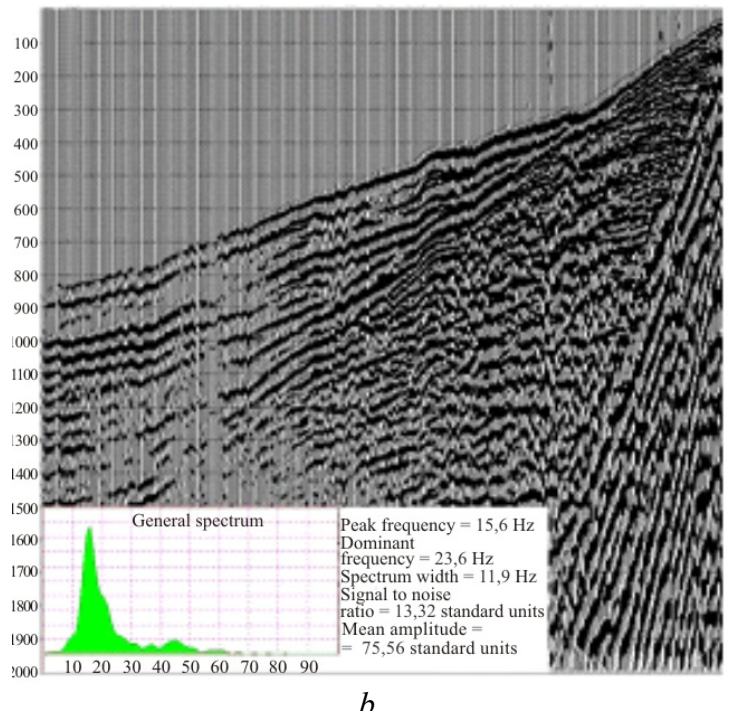

$b$

Fig. 3. Wave pattern registered using GS-ONE single seismic receivers $(a)$ and $G S-20 D X$ geophone groups $(b)$

These works offer a practical value due to the fact that hard-to-reach areas are seldom included in the scope of seismic exploration works, whereas the wells that are drilled in them hardly ever undergo geophysical surveys. In these conditions, unreliable seismic data can deteriorate reliability of recommendations for a well laying [14], which entails significant financial risks.

Seismic signal recording was conducted via two receiver lines, using groups of twelve GS-20 DX geophones on the one line and GS-ONE single seismic receivers on the other. The receiver lines were unreeled alongside one another in identical surface conditions. Regardless of the type of surface conditions, the seismic dataset obtained using GS-ONE seismic receivers has certain differences from the data obtained using $G S$-20 DX geophones. In the first case, the wave pattern contains a wider spectrum of registered frequencies but with smaller amplitudes (Fig. 2) and is confounded by noise influences, which are especially obvious in the microseism area (Fig. 3, a). Wind is the main noise event, which is quite difficult to exclude during the recording, but it can be suppressed during processing by powerful tools designed for this purpose $[15,16]$. Excessive levels of noise are caused by a higher sensitivity of $G S-O N E$ single seismic receivers, amounting to $78.7(\mathrm{~V} / \mathrm{m} / \mathrm{s})$ against $19.7(\mathrm{~V} / \mathrm{m} / \mathrm{s})$ of one GS-20DX device [17]. A higher level of amplitudes in using a group of geophones (Fig. 3, b) is achieved through the group statistic effect [18, 19]. The attenuation effect of the surface-type noise waves through grouping was not fully achieved in these conditions. Probably, the geophone group (being an interference system) failed to provide a sufficient degree of the intense noise wave suppression due to the NSS complex structure, fluctuations of kinematic and dynamic parameters of useful waves and noise effects.

Another reason of this failure was that the noise wave suppression technology was designed as a system customizable to the individual elastic wave fields that vary across regions [20, 21, 22]. Grouping seismic receivers with constant parameters not only reduce the noise wave suppression capability, but also distort them upon recording, which is counterintuitive, taking into account the existing methods for surface waves' interpretation [23].

Notably, the use of single seismic receivers makes reeling and unreeling of the field equipment significantly easier, as the weight and size of $G S-O N E$ receivers is much less (about $0.2 \mathrm{~kg}$ vs. almost $2.0 \mathrm{~kg}$ weight of $G S-20 \mathrm{DX}$ ), which enables a more effective use of the seismic crew personnel, thus, improves the overall performance and reduces the costs of the field operations [24].

At the stage of the seismic data processing, time sections obtained using the single seismic receivers will be taken into account. However, further analysis of the primary seismic data will only be based on the materials obtained using GS-20 DX geophones, since the wave pattern they produce is more expressive and visually representative. 
The seismic signal excitation in the test profile was achieved using a traditional method with shallow drilling (down to $10 \mathrm{~m}$ ) and the technology for blast charge laying below the base of the low-velocity layer (LVL) at the depth of 20 and $30 \mathrm{~m}$. Besides, Geoton-15 compact pulse source was used as the vibration excitation source. The device belongs to the new generation of pulse sources and meets the requirements of environmentally safe operations.

In the southern, dry-land part of the profile, sandand-gravel deposits occur at the depth below $25 \mathrm{~m}$. These conditions adversely impact the seismic signal excitation, which affects the wave pattern obtained when the blast charge was placed at a depth of $30 \mathrm{~m}$. Compared to the seismogram registered with the 20-m charge depth, it has lower amplitude-frequency characteristics. The difference between the records from the depths of $20 \mathrm{~m}$ and $8 \mathrm{~m}$ is minimal. The seismogram obtained from the eight-meter well has a more pronounced sound wave train, which has somewhat narrowed the frequency spectrum, but can be easily excluded at the stage of the seismic data processing. Fig. 4 (I) shows the amplitude-frequency characteristics of the seismic records obtained during the works in the dry land part of the profile, where it is clear how quickly the seismic signal attenuates when excited from the depth of $30 \mathrm{~m}$.

In the central, swampy part of the profile, the record obtained from the signal excitation at the depth of $30 \mathrm{~m}$ shows an apparent continued impact of sandy deposits on the amplitude-frequency characteristics of the signal (Fig. 4, II $a$ ), albeit less than in the forested part. The records obtained from the depths of $20 \mathrm{~m}$ and $8 \mathrm{~m}$ differ by frequency: the eight-meter record has a narrower spectrum, associated with the influence of low-frequency noise waves, which intensity grows as the blast charge laying depth decreases.

The data shown in Fig. 4 (II, $b, c$ ) make it possible to trace the impact of the low-frequency constituent of the record on the general wave pattern; the spectrum becomes narrower.

Based on the assessment of the primary seismic data, a conclusion was made that blast charge positioning below the LVL base is not always justified: seismic signal generation depends to a larger extent on the immediate lithological conditions of the charge placement than on the depth of its embedding.

In order to obtain reliable high quality field data in the conditions of swampy areas, it is necessary to know exactly the depth of the swamp's bottom, since it is crucial to place the charge in a dense rock. Apart from establishing favorable conditions for seismic signal excitation, the opportunity to observe these parameters will help to avoid the risk of the charge surfacing, which is against the safety rules of blasting operations [25].

The described situation suggests a high degree of NSS lateral inhomogeneity, posing yet another challenge to the seismic exploration, i.e. a detailed forecast of NSS lithological composition in order to determine the optimum charge laying depth. The microseismic logging is a sufficiently reliable method for the necessary forecast, but it proves to be cost ineffective at high well spacing density. As a rule, a network with a density of 1 well per $1 \mathrm{~km}^{2}$ is used, which does not provide a detailed picture of NSS lateral variability.

It has recently become popular to combine seismic exploration works with geoelectric surveying. We believe one of these methods to be quite promising. In particular, it is the continuous

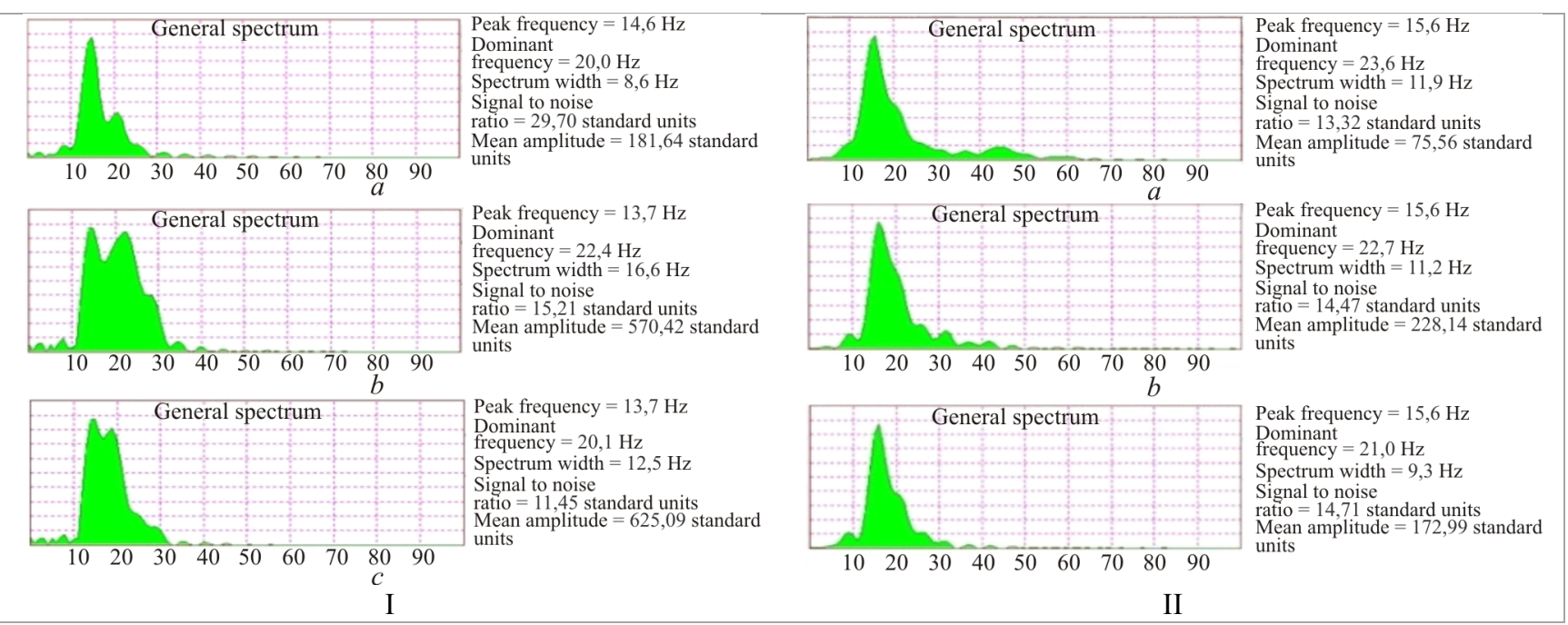

Fig. 4. Amplitude-frequency curves of records obtained by blasting: I) on land in a well with the depth of $30 \mathrm{~m}(a), 20 \mathrm{~m}(b)$ and $8 \mathrm{~m}(c)$; II) in a swamp in a well with the depth of $30 \mathrm{~m}(a), 20 \mathrm{~m}(b)$ and $8 \mathrm{~m}(c)$ 
electromagnetic scanning (EMS) of the section using the method of time-domain electromagnetics and georadar profiling (GRP) [26, 27]. The results obtained by this technology confirm feasibility and effectiveness of the method for NSS study.

The seismic vibration pulse source Geoton-15 represents an alternative means of exploration in swampy areas. It is compact, low-weight, deforms the surface insignificantly during use and is convenient for transportation in groups or individually. These features make it a good option for exclusive zones such as various types of water areas, environmentally restricted areas, inhabited areas, or industrial areas. Notably, PJSC Permneftegeofizika specialists developed an effective system aimed at conducting the seismic exploration works in water areas and bottom drilling from ice during winter seasons [28]. However, the authors of this method [29] confirm that this technology is unfeasible in channel parts of the water areas with a layer over $10 \mathrm{~m}$.

The Geoton source can be used in almost any territory [30]. Slavneft-NPC LLC has demonstrated a unique example of its use for seismic signal excitation during seismic exploration works using the 3D common depth point method in the East Lokosovskoe field area in extremely complicated surface conditions, including the main channel and flood plain of the river $\mathrm{Ob}$. The use of pulse sources resulted in minimizing irregularities of the employed acquisition systems.

In ice cover areas, the Geoton sources were successfully used [31]. It is notable that a group of sources towed by an all-terrain vehicle still has certain limitations as to the minimum ice thickness, since its weight reaches 10 tons. This is much less than the large sources like Yenisey [32], but quite a lot during warm winters that are more often now. From time to time researchers discuss the possibility of creating even lighter sources, however, a pulse that would be sufficiently powerful to ensure the exploration depth exceeding $1 \mathrm{~km}$, has to be produced by a source having a respectively large weight [33-36].

In the course of the aforementioned works, the Geoton source has been used in Perm Krai for the first time. The wave pattern registered during the dry-land part of the exploration area appeared to be quite different from the acquisitions in the swamps. In the dry land, the obtained data were comparable to the blast data, first events were clear, fragments of the reflected waves were visible in the primary material (Fig. 5, a). The record registered in the swampy conditions was distorted by powerful low-frequency noise waves associated with the unstable icy bed of the swamp surface and caused by the surface swaying effect during the source operation (Fig. 5, $b$ ).
However, seismic exploration is a complex and staged process where the primary data obtaining is just the first step. A.V. Cherepovsky, a well-known Russian scholar working in seismic exploration studies, stated in his book, "many geophysics still stick to the old belief that if there is no (visible) signal in the initial data, it will not appear in the final sections. The time has come to call this idea in question."[37]

A priori time sections (after summation but before processing) obtained using a blast source located below the LVL base have the best quality of summation; reflections correlate practically throughout the entire recording interval.

A priori sections obtained using the blast source from the depth of $8 \mathrm{~m}$ show a great impact of the noise waves (especially in the swampy part of the profile).

The lowest summation quality and almost a complete lack of the reflections in the target intervals were obtained in the time sections with the pulse source (Fig. 6, $c$ ).
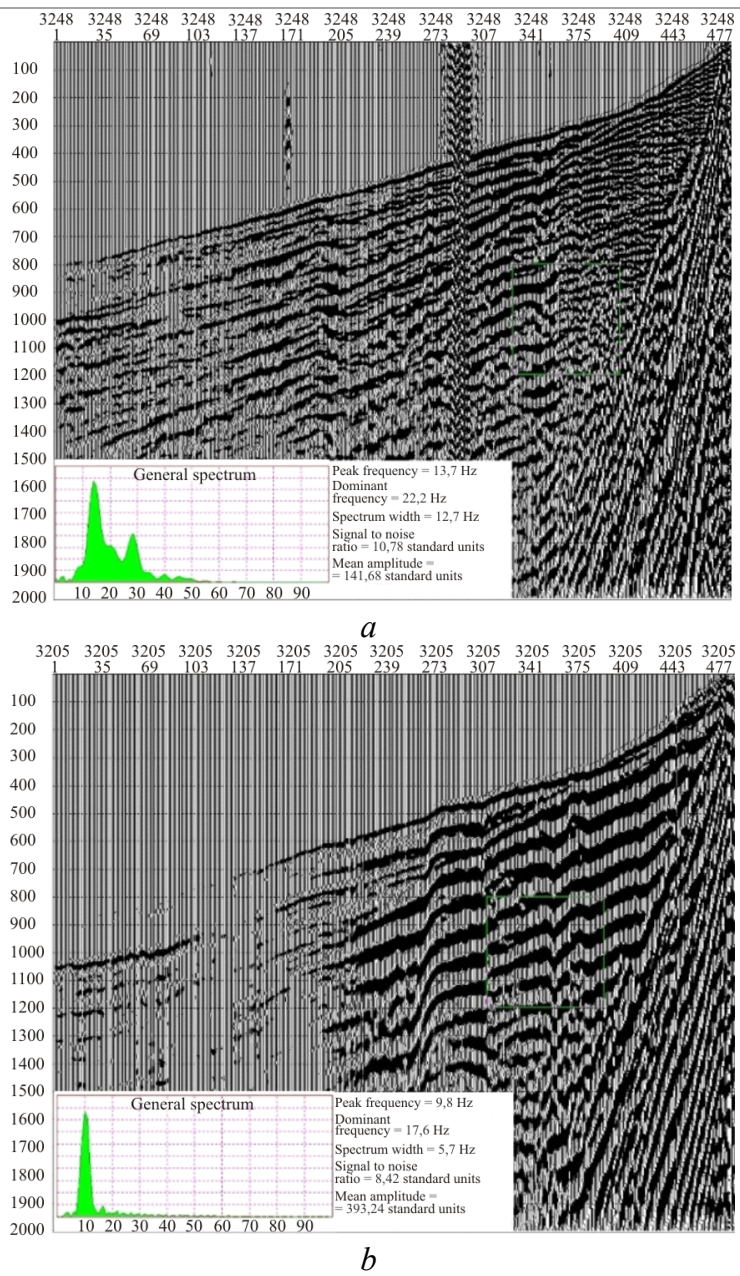

Fig. 5. A seismic record registered as a result of the signal excitation by a group of sixteen Geoton- 15 pulse sources on a dry land $(a)$ and in a swamp $(b)$ 


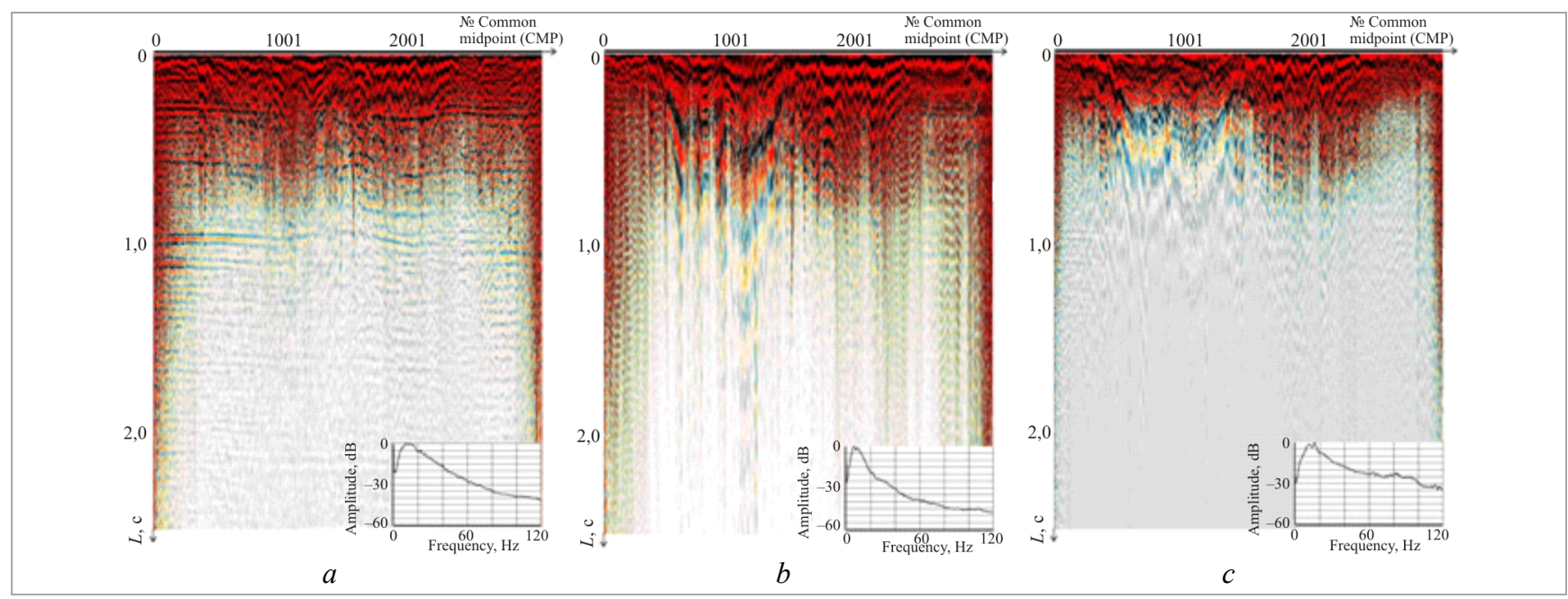

Fig. 6. A priori time sections. A blast in a well with the depth of $20 \mathrm{~m}(a), 8 \mathrm{~m}(b)$ and Geoton pulse source data $(c)$

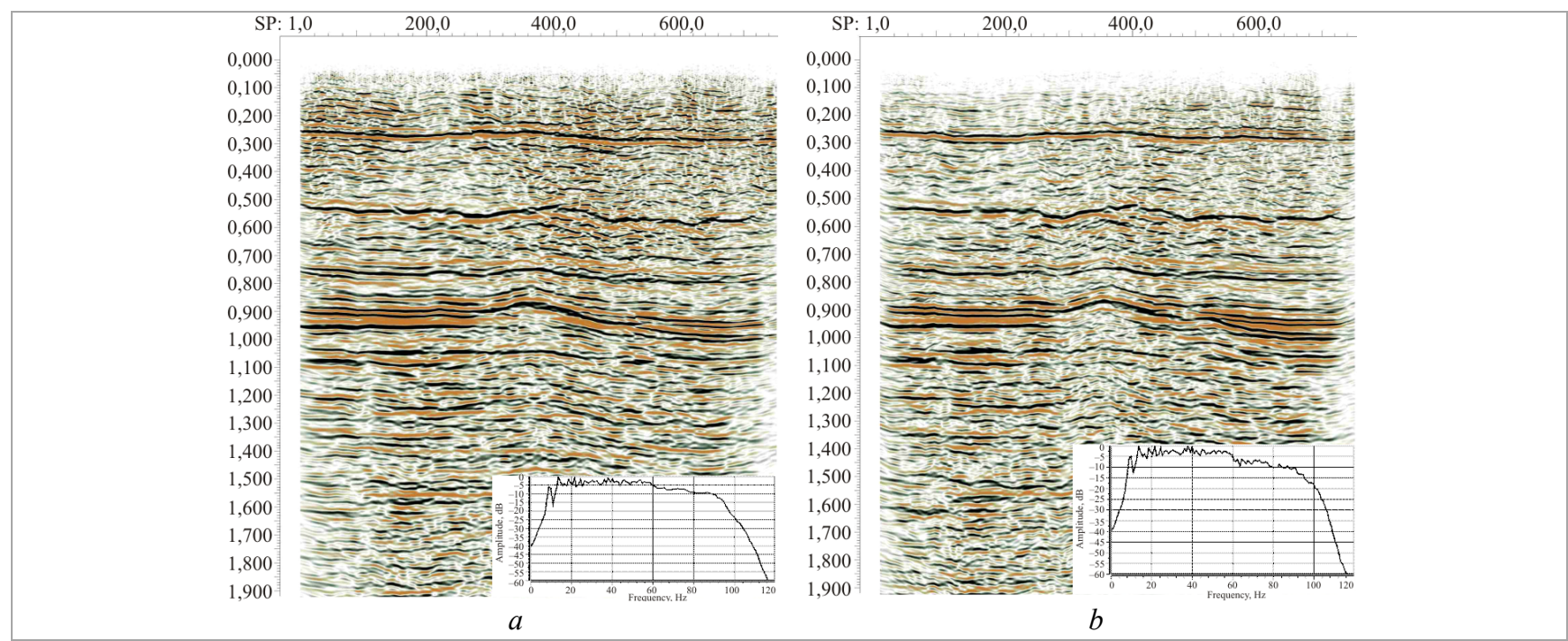

Fig. 7. Time sections: a blast in a well with the depth of $20 \mathrm{~m}(a)$ and $8 \mathrm{~m}(b)$

As mentioned earlier, it would be counterintuitive to make conclusions about the quality of seismic data without considering material processing results. The processing is intended for extraction of useful information from the field seismic data. The seismic data processing is mostly based on solving inverse problems. An inverse problem in seismic exploration deals with determining the structure of the seismogeological environment from the acquisitions of the elastic wave field occurring in it $[38,39]$.

A poor quality of a priori summation is related to the influence of the surface noise waves that typically have low frequencies and large amplitudes. At the final processing stage, time sections for all the excitation sources have demonstrated the quality acceptable for a further interpretation. It is clear that achievement of such a result requires a detailed control of processing [40, 41].
According to the processed results, the best-quality material in terms of wave field characteristics (higher coherence and record resolution in time sections) was in case of using the blast excitation sources. Sections are mostly comparable for the charge laying depths of 8 meters and 20 meters (Fig. 7).

The time section with the pulse source of excitation showed a lower performance against the blast source having produced a narrower frequency spectrum and accuracy (Fig. 8); therefore, it may be limited in terms of the capability of a small target interpretation [42].

Nevertheless, owing to its technical features, simplicity and safety of the operation, the Geoton pulse source represents an attractive alternative source of the seismic signal excitation.

The present study and negotiations with the source manufacturer revealed certain details that may result in 


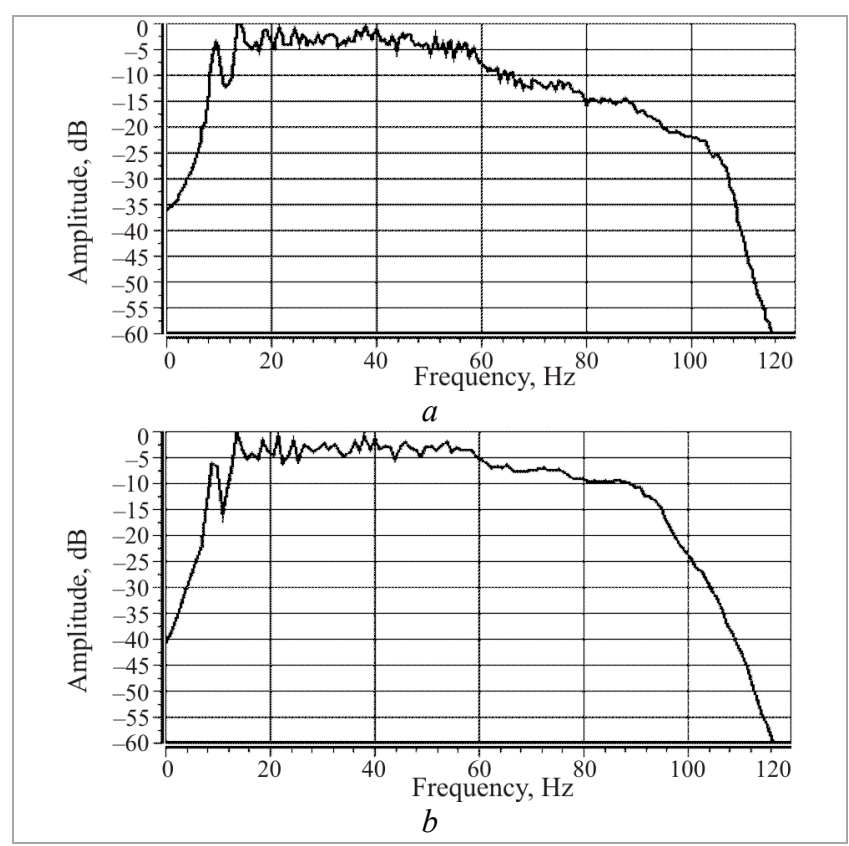

Fig. 8. Frequency spectra of time sections obtained by signal excitation using the pulse $(a)$ and blast $(b)$ source

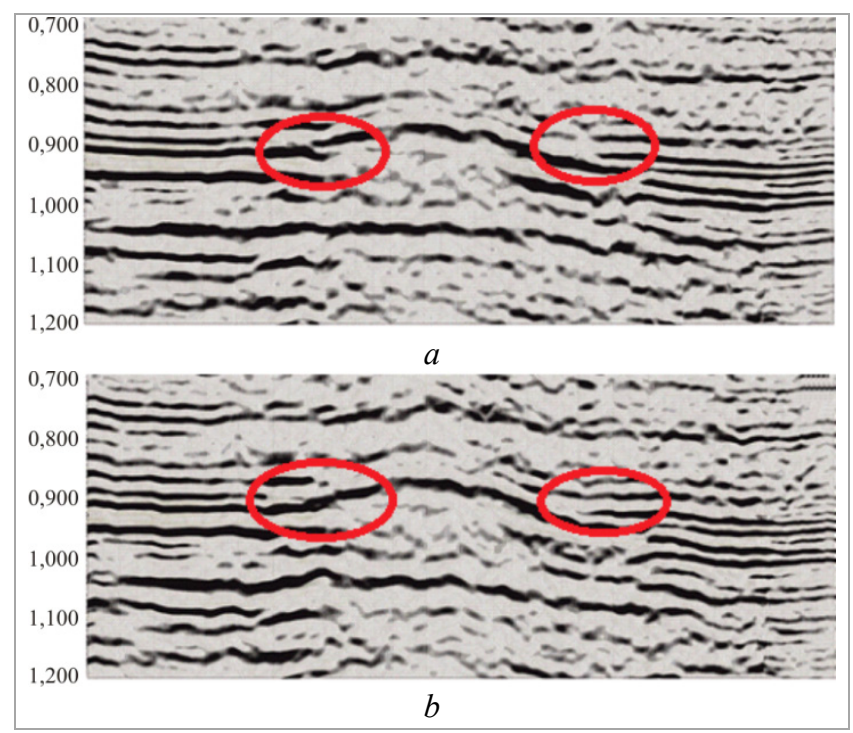

Fig. 9. Time sections built on the data obtained using $G S-20$ $D X$ geophones $(a)$ and $G S-O N E$ single seismic receivers $(b)$ low-amplitude faults (Fig. 9). Notably, for single receivers placed with the sufficient density (at an interval of 10-12 m), the laboratory grouping is available, referred to as effective by many researchers $[43-45]$

improving the frequency spectrum of the generated elastic waves, thereby increasing the level of the wave pattern accuracy.

As for the grouping impact of the seismic receivers and single geophones on the wave pattern, it has been discovered that in the context of these works, there is only a small difference in the accuracy of the reflecting horizons tracing. The single receivers tend to produce a more detailed picture of small-sized targets and low- amplitude faults (Fig. 9). Notably, for single receivers placed with the sufficient density (at an interval of $10-12 \mathrm{~m}$ ), the laboratory grouping is available, referred to as effective by many researchers [43-45].

\section{Conclusion}

1. Time sections obtained using different excitation sources have nearly $100 \%$ traceability of the target reflections followed by processing, but the blast sources perform better in terms of detail and resolution.

2. After the entire set of the data processing operations, the sections with the blast excitation source in the wells with the depth of 8 meters and 20 meters showed an equal quality of the target reflections. Therefore, it appears to be counterintuitive to drill deeper wells that require much more funds and efforts. Special attention should be paid to analyzing the NSS lithological features when selecting the blast charge laying depth.

3. It is advisable to conduct a preliminary study of the NSS structure using methods alternative to the seismic exploration, e.g. EMS and GRP showed promising results. The detailed picture of the NSS lithological structure will help to avoid the charge placement in adverse conditions and exclude an excessively deep laying.

4. The pulse sources produce time sections with a lower resolution and detail. Nevertheless, if we consider the seismogeological area complexity, lack of their field use experience and novelty of such materials for processing, we believe that such sources might be helpful, especially in the works conducted in the zones highly sensitive in terms of environmental protection and safety.

5. The single seismic receivers have demonstrated a final result comparable to that obtained using the groups of geophones. The former have an advantage of producing more detailed time sections, whereas the undoubted convenience and lightweight of the field equipment reduce the unreeling efforts.

\section{Acknowledgements}

The author is grateful to LUKOIL PERM LLC for the opportunity to conduct the pilot works, and PJSC Permneftegeofizika for conducting the production cycle of works.

\section{References}

1. Liakhov G.M. Volny $\mathrm{v}$ gruntakh i poristykh mnogokomponentnykh sredakh [Waves in soils and porous multicomponent media]. Moscow: Nauka, $1982,288 \mathrm{p}$. 
2. Dalmatov B.I. Mekhanika gruntov, osnovaniia i fundamenty [Soil mechanics, foundations and foundations]. Moscow: Stroiizdat, 1981, 319 p.

3. Nanishvili O.A. Uchet neodnorodnostei verkhnei chasti razreza (VChR) pri obrabotke seismorazvedochnykh dannykh [The accounting of inhomogeneity the upper part in the processing of seismic data]. Vestnik Iugorskogo gosudarstvennogo universiteta, 2017, iss. 4, p. 17.

4. Kozyrev V.S. Uchet neodnorodnostei verkhnei chasti razreza $\mathrm{v}$ seismorazvedke. Sovremennye tekhnologii [Taking into account heterogeneities of the upper part of the section in seismic exploration. Modern technologies]. Moscow: Nedra-Biznestsentr, 2003, 227 p.

5. Mitiunina I.Iu. Pervye volny na seismogrammakh MOV i izuchenie verkhnei chasti razreza [The first waves in the seismograms of the MOV and the study of the upper part of the section]. Geofizika, 2003, no. 5, pp. 5-12.

6. Spasskii B.A. Izuchenie VChR po pervym vstupleniiam v MOGT [The study of VLD on the first entry into the IOGT]. Regional'naia, razvedochnaia $i$ promyslovaia geofizika, 1982, iss. 19, pp. 1-13.

7. Spasskii B.A. Izuchenie VChR po pervym vstupleniiam $v$ MOGT [On increasing the efficiency of calculating static corrections in the IOGT]. Geofizicheskie metody poiskov $i$ razvedki mestorozhdenii nefti $i$ gaza. Perm, 1984, pp. 36-44.

8. Spasskii B.A. Ispol'zovanie pervykh voln v seismorazvedke metodom otrazhennykh voln dlia izucheniia verkhnei chasti razreza [The use of the first waves in seismic exploration by the method of reflected waves to study the upper part of the section]. Moscow: Geoinformmark, 1992, p. 46.

9. Pritchett W.C. Acquiring Better Seismic Data. Springer Netherlands, 1990, $428 \mathrm{p}$.

10. Dolgikh Iu.N. Mnogourovnevaia seismorazvedka i kinematicheskaia inversiia dannykh MOVOGT v usloviiakh neodnorodnoi VChR [Multilevel seismic exploration and kinematic inversion of MOV-OGT data in the conditions of non-uniform RF]. Moscow: EAGE Geomodel', 2014, p. 54.

11. Laptev A.P., Salovskii V.A., Lantsev V.F. Transportabel'nyi kompleks dlia provedeniia trekhmernykh seismorazvedochnykh rabot 3D [Transportable complex for carrying out threedimensional 3D seismic operations]. Patent Rossiiskaia Federatsiia no. 61894, 2006.

12. Neganov V.M. Seismogeologicheskoe raionirovanie Permskogo kraia $\mathrm{V}$ sviazi $\mathrm{s}$ sovershenstvovaniem metodiki dal'neishikh geofizicheskikh rabot na neft' i gaz [Seismogeological zoning of the Perm Territory in connection with the improvement of the methodology for further geophysical work on oil and gas]. Ph. D. thesis. Perm, OAO PNG. FGUDP "KamNIIKIGS", 2006, 174 p.

13. Cherepovskii V.E., Zhgetin S.A. Izuchenie verkhnei chasti razreza i vybor uslovii vzryvnogo vozbuzhdeniia dlia seismorazvedki vysokogo razresheniia [The study of the upper part of the section and the choice of explosive excitation conditions for high-resolution seismic surveys]. Razvedochnaia geofizika. Moscow: Nedra, 1985, no. 100.

14. Schut E.W., Uenzelmann-Neben G. Tying seismic data to geologic information from core data. GEO-MARINE LETTERS, 2006, vol. 26, no. 4, pp. 235-248.

15. Guanghui L., Yue L., Baojun Y. Effect of wind on seismic exploration random noise on land: Modeling and analyzing. Journal of Applied Geophysics, 2015, vol. 119, pp. 106-118.

16. Chang D.K., Yang W.Y., Wang Y.H., Yang Q., Wei X.J., Feng X.Y. Random noise suppression for seismic data using a non-local Bayes algorithm. Journal of Applied Geophysics, 2018, vol. 15, pp. 91-98.

17. Shi Jung Chen, Ch. Dalton. Theoretical and experimental approaches to the geophone spurious frequency. Geophysical Prospecting. November, 2015, vol. 31, iss. 4.

18. Gol'tsman F.M. Osnovy teorii interferentsionnogo priema reguliarnykh voln [Fundamentals of the theory of interference reception of regular waves]. Moscow: Nauka, 1964, 283 p.

19. Hales F.W., Edwards T.E. Some theoretical considerations on the use of multiple geophones arranged linearly along the line of traverse. Geophysical Prospecting, 1955, vol. 3, iss. 1.

20. Shestakov E.S., Veselov N.A. Otsenka napravlennykh svoistv slozhnykh interferentsionnykh sistem, formiruiushchikhsia pri provedenii seismorazvedochnykh rabot MOV [Evaluation of the directed properties of complex interference systems formed during seismic exploration of the MOV]. Nedra Povolzh'ia $i$ Prikaspiia. Saratov, 2018, no. 93 , pp. 62-72.

21. Guofa Li, Hao Zheng, Jingjing Wang, Wei Huang Inversion-based directional deconvolution to remove the effect of a geophone array on seismic signal. Journal of Applied Geophysics, 2016, vol. 130, pp. 91-100.

22. Giancarlo Dal Moroa, Rui Miguel Marques Moura, Sayed S.R. Moustafacd Multi-component joint analysis of surface waves. Journal of Applied Geophysics, 2015, vol. 119, pp. 128-138.

23. Schuster Gerard T., Jing Li, Kai Lu, Ahmed Metwally, Abdullah AlTheyab, Sherif Hanafy. Opportunities and pitfalls in surface-wave interpretation. Interpretation, 2017, vol. 5, iss. 1, pp. 1F-T141. 
24. Yibirin R., Lacruz A., Caldwell J. Sravnenie rezul'tatov polevykh ispytanii geofonov pri vypolnenii seismorazvedochnykh rabot po metodike 2D v Kolumbii [Comparison of field test results for geophones when performing 2D seismic surveys in Colombia]. Pribory i sistemy razvedochnoi geofiziki, 2013, vol. 43, no. 1(43), pp. 60-64.

25. Bezopasnost' pri vzryvnykh rabotakh: sbornik normativnykh dokumentov [Blasting Safety: A Collection of Regulatory Documents]. Moscow: Zakrytoe aktsionernoe obshchestvo "Nauchno-tekhnicheskii tsentr issledovanii problem promyshlennoi bezopasnosti", 2012, $81 \mathrm{p}$.

26. Riaboshapko S.M., Tsypyshev N.N. et al. Prognozirovanie optimal'nykh uslovii razmeshcheniia zariada pri seismorazvedochnykh rabotakh $\mathrm{v}$ Zapadnoi Sibiri s ispol'zovaniem elektromagnitnogo skanirovaniia vo vremennoi oblasti [Prediction of optimal conditions for the charge placement during seismic operations in western siberia using electromagnetic scanning in the time domain]. Pribory $i$ sistemy razvedochnoi geofiziki, 2014, no. 4, pp. 70-83.

27. Sudakova M.S., Vladov M.L. Sovremennye napravleniia georadiolokatsii [The influence of conductivity on the reflected ground penetrating radar signal amplitude]. Vestnik Moskovskogo universiteta. Geologiia, 2018, no. 2, pp. 3-12.

28. Laptev A.P., Salovskii V.A., Lantsev V.F. Sposob seismicheskoi razvedki [Seismic exploration method]. Patent Rossiiskaia Federatsiia, no. 2369882, 2006.

29. Laptev A.P., Roshmakov Iu.V. Seismorazvedka MOGT 3D $v$ zimnikh usloviiakh na nizhnekamskom vodokhranilishche [3D seismic survey in winter on the reservoir of nizhnekamsk]. Geofizika, 2013, no. 5, 34 p.

30. Iurov A.A., Lopukhov G.P., Gur'ev S.V. Impul'snyi elektromagnitnyi istochnik "Geoton-15". Opyt prakticheskogo primeneniia [Pulsed electromagnetic source "Geoton-15". Practical experience]. Pribory i sistemy razvedochnoi geofiziki, 2013, no. 3, pp. 49-53.

31. Safarov Iu.N., OOO "Slavneft'-NPTs". Opyt primeneniia impul'snykh istochnikov "ENISEI» i «GEOTON» pri seismorazvedochnykh rabotakh na litsenzionnykh uchastkakh OAO "NGK "Slavneft" [Experience with the use of impulse sources "YENISEY" and "GEOTON" during seismic surveys in the licensed areas of OAO NGK Slavneft]. Pribory $i$ sistemy razvedochnoi geofiziki, 2015, no. 47, 37 p.

32. Detkov V.A. Impul'snye nevzryvnye istochniki seismorazvedki s elektromagnitnym privodom [Pulsed explosive souces of prospecting seismology With electromagnetic drive]. Sibirskii zhurnal nauki $i$ tekhnologii, 2009, pp. 119-122.
33. Herbst R., Kapp I., Krummel H., Lück E. Seismic sources for shallow investigations: A field comparison from Northern Germany. Journal of Applied Geophysics, 1998, vol. 38, iss. 4, pp. 301-317.

34. Ivashin V.V., Iannikov N.A. K voprosu sozdaniia perenosnykh impul'snykh nevzryvnykh seismoistochnikov $\mathrm{s}$ induktsionno-dinamicheskim privodom [To question about the creation a portable pulse of non explosive seismic source with electrodynamic drive]. Izvestiia Samarskogo nauchnogo tsentra Rossiiskoi akademii nauk. Самара, 2013, pp. 75-80.

35. Sawasdee Yordkayhun, Jumras $\mathrm{Na}$ Suwan. A university-developed seismic source for shallow seismic surveys. Journal of Applied Geophysics, 2012, vol. 82, pp. 110-118.

36. Mohamed A. Rashed. GDP: A new source for shallow high-resolution seismic exploration. Journal of Applied Geophysics, 2009, vol. 68, iss. 2, pp. 243-248.

37. Cherepovskii A.V. Nazemnaia seismorazvedka novogo tekhno-logicheskogo urovnia [Ground-based seismic exploration of a new technological level]. Moscow: EAGE Geomodel', 2016, 27 p.

38. Boganik G.N., Gurvich I.I. Seismorazvedka [Seismic exploration]. Tver: AIS, 2006, 369 p.

39. Bondarev V.I. Seismorazvedka [Seismic exploration]. Ekaterinburg: Ural'skii gosudarstvennyi gornyi universitet, 2007, $703 \mathrm{p}$.

40. Araman A., Paternoster B. Seismic quality monitoring during processing. FIRST BREAK, 2014, vol. 32, pp. 69-78.

41. Feoktistov A.V., Feoktistov V.A. Zachem nuzhen supervaizer? [Why do I need a supervisor?]. Nedra Povolzh'ia $i$ Prikaspiia, 2010, iss. 62, pp. 67-75.

42. Khisamov R.S., Gatiiatullin N.S., Tarasov E.A., Liberman V.B. Osobennosti geologorazvedochnykh rabot $\mathrm{V}$ raionakh $\mathrm{s}$ vysokoi osvoennost'iu nedr (na primere Respubliki Tatarstan) [Geological exploration in the highly explored regions of Tatarstan)]. Georesursy, 2008, iss. 27, pp. 26-28.

43. Bagaini C., Barajas Olalde C. Assessment and compensation of inconsistent coupling conditions in point receiver land seismic data. Geophysical Prospecting, 2007, vol. 55, iss. 1.

44. Mikheev S.I., Seleznev V.A., Zub E.A. Novye Tekhniko-metodicheskie priemy polevykh seismorazvedochnykh rabot [New Technological and methodological techniques for field seismic surveys]. Nedra Povolzh'ia i Prikaspiia, 2014, iss. 79, pp. 30-39.

45. Kostrygin Iu.P., Kostrygina A.A. Gruppirovanie seismopriemnikov i seismicheskikh izluchatelei [Grouping of seismic receivers and seismic emitters]. Krasnodar: Kubanskii gosudarstvennyi universitet, 2018, $58 \mathrm{p}$. 


\section{Библиографический список}

1. Ляхов Г.М. Волны в грунтах и пористых многокомпонентных средах. - М.: Наука, 1982. -288 c.

2. Далматов Б.И. Механика грунтов, основания и фундаменты. - М.: Стройиздат, 1981. -319 с.

3. Нанишвили О.А. Учет неоднородностей верхней части разреза (ВЧР) при обработке сейсморазведочных данных // Вестник Югорского государственного университета. - 2017. Вып. 4. - С. 17.

4. Козырев В.С. Учет неоднородностей верхней части разреза в сейсморазведке. Современные технологии. - М.: Недра-Бизнесцентр, 2003. - 227 с.

5. Митюнина И.Ю. Первые волны на сейсмограммах $\mathrm{MOB}$ и изучение верхней части разреза // Геофизика. - 2003. - № 5. - С. 5-12.

6. Спасский Б.А. Изучение ВЧР по первым вступлениям в МОГТ // Региональная, разведочная и промысловая геофизика. ЭИ ВИЭМС. М., 1982. - Вып. №19. - С. 1-13.

7. Спасский Б.А. О повышении эффективности расчета статических поправок в МОГТ // Геофизические методы поисков и разведки месторождений нефти и газа. - Пермь: Изд-во Пермск. ун-та, 1984. - С. 36-44.

8. Спасский Б.А. Использование первых волн в сейсморазведке методом отраженных волн для изучения верхней части разреза. М.: Геоинформмарк, 1992. - С. 46.

9.Pritchett W.C. Acquiring better seismic data. Springer Netherlands, 1990. - P. 428.

10. Долгих Ю.Н. Многоуровневая сейсморазведка и кинематическая инверсия данных МОВ-ОГТ в условиях неоднородной ВЧР. М.: ЕАГЕ Геомодель, 2014. - С. 54.

11. Лаптев А.П., Саловский В.А., Ланцев В.Ф. Транспортабельный комплекс для проведения трехмерных сейсморазведочных работ 3D: патент на полезную модель 61894. М.: РОСПАТЕНТ, 2006.

12. Неганов В.М. Сейсмогеологическое районирование Пермского края в связи с совершенствованием методики дальнейших геофизических работ на нефть и газ: дис. ... канд. геол.-мин. наук / ОАО ПНГ. ФГУДП «КамНИИКИГС». - Пермь, 2006. $-174 \mathrm{c}$.

13. Череповский В.Е., Жгетин С.А. Изучение верхней части разреза и выбор условий взрывного возбуждения для сейсморазведки высокого разрешения // Разведочная геофизика. - М.: Недра, 1985. - № 100.

14. Schut E.W., Uenzelmann-Neben G. Tying seismic data to geologic information from core data //
GEO-MARINE LETTERS. - 2006. - Vol. 26, № 4. P. 235-248.

15. Guanghui L., Yue L., Baojun Y. Effect of wind on seismic exploration random noise on land: Modeling and analyzing // Journal of Applied Geophysics. 2015. - Vol. 119. - P. 106-118.

16. Random noise suppression for seismic data using a non-local Bayes algorithm / D.K. Chang, W.Y. Yang, Y.H. Wang, Q. Yang, X.J. Wei, X.Y. Feng // Journal of Applied Geophysics. - 2018. - Vol. 15. P. 91-98.

17. Shi Jung Chen, Ch. Dalton. Theoretical and experimental approaches to the geophone spurious frequency // Geophysical Prospecting. - November, 2015. - Vol. 31, iss. 4.

18. Гольцман Ф.М. Основы теории интерференционного приема регулярных волн. М.: Наука, 1964. - С. 283.

19. Hales F.W., Edwards T.E. Some theoretical considerations on the use of multiple geophones arranged linearly along the line of traverse // Geophysical Prospecting. - 1955. - Vol. 3, iss. 1.

20. Шестаков Э.С., Веселов Н.А. Оценка направленных свойств сложных интерфернционных систем, формирующихся при проведении сейсморазведочных работ МОВ // Недра Поволжья и Прикаспия. - Саратов, 2018. - Вып. № 93. C. $62-72$.

21. Inversion-based directional deconvolution to remove the effect of a geophone array on seismic signal / Li Guofa, Zheng Hao, Wang Jingjing, Huang Wei // Journal of Applied Geophysics. - 2016. - Vol. 130. P. $91-100$.

22. Giancarlo Dal Moroa, Rui Miguel Marques Moura, Sayed S.R. Moustafacd multi-component joint analysis of surface waves // Journal of Applied Geophysics. - 2015. - Vol. 119. - P. 128-138.

23. Opportunities and pitfalls in surface-wave interpretation / T. Schuster Gerard, Li Jing, Lu Kai, Metwally Ahmed, AlTheyab Abdullah, Hanafy Sherif // Interpretation. - 2017. - Vol. 5, iss. 1. P. $1 \mathrm{~F}-\mathrm{T} 141$.

24. Yibirin R., Lacruz A., Caldwell J. Сравнение результатов полевых испытаний геофонов при выполнении сейсморазведочных работ по методике $2 \mathrm{D}$ в Колумбии // Приборы и системы разведочной геофизики. - 2013. - Вып. № 43. - С. 60-64.

25. Безопасность при взрывных работах: сборник нормативных документов. - М.: Изд-во ЗАО НТЦ ПБ, 2012. - С. 81.

26. Прогнозирование оптимальных условий размещения заряда при сейсморазведочных работах в Западной Сибири с использованием электромагнитного сканирования во временной области / С.М. Рябошапко, Н.Н. Цыпышев [и др.] // Приборы 
и системы разведочной геофизики. - 2014. - № 4. C. $70-83$.

27. Судакова М.С., Владов М.Л. Современные направления георадиолокации // Вестник Московского университета. Серия 4: Геология. 2018. - № 2. - C. 3-12.

28. Лаптев А.П., Саловский В.А., Ланцев В.Ф. Способ сейсмической разведки: патент на изобретение № 2369882. - М.: РОСПАТЕНТ, 2006.

29. Лаптев А.П., Рошмаков Ю.В. Сейсморазведка МОГТ 3D в зимних условиях на нижнекамском водохранилище // Геофизика. 2013. - № 5. - С. 34.

30. Юров А.А., Лопухов Г.П., Гурьев С.В. Импульсный электромагнитный источник «Геотон15». Опыт практического применения // Приборы и системы разведочной геофизики. - 2013. - № 3. C. 49-53.

31. Сафаров Ю.Н., ООО «Славнефть-НПЦ». Опыт применения импульсных источников «ЕНИСЕЙ» и «ГЕОТОН» при сейсморазведочных работах на лицензионных участках ОАО «НГК “Славнефть”»// Приборы и системы разведочной геофизики. - 2015. - № 47. - С. 37.

32. Детков В.А. Импульсные невзрывные источники сейсморазведки с электромагнитным приводом // Сибирский журнал науки и технологий. 2009. - С. 119-122.

33. Seismic sources for shallow investigations: A field comparison from Northern Germany / R. Herbst, I. Kapp, H. Krummel, E. Lück // Journal of Applied Geophysics. - 1998. - Vol. 38, iss. 4. P. 301-317.

34. Ивашин В.В., Ианников Н.А. К вопросу создания переносных импульсных невзрывных сейсмоисточников $\mathrm{c}$ индукционно-динамическим приводом // Известия Самарского научного центра Российской академии наук. - Самара, 2013. С. $75-80$.
35. Sawasdee Yordkayhun, Jumras Na Suwan. A university-developed seismic source for shallow seismic surveys // Journal of Applied Geophysics. 2012. - Vol. 82. - P. 110-118.

36. Mohamed A. Rashed. GDP: A new source for shallow high-resolution seismic exploration // Journal of Applied Geophysics. - 2009. - Vol. 68, iss. 2. P. 243-248.

37. Череповский А.В. Наземная сейсморазведка нового технологического уровня. - М.: ЕАГЕ Геомодель, 2016. - С. 27.

38. Боганик Г.Н., Гурвич И.И. Сейсморазведка: учеб. для вузов. - Тверь: Изд-во АИС, 2006. - С. 369.

39. Бондарев В.И. Сейсморазведка: учеб. для вузов. - Екатеринбург: Изд-во Уральск. гос. горн. ун-та, 2007. - С. 703.

40. Araman A., Paternoster B. Seismic quality monitoring during processing // FIRST BREAK. 2014. - Vol. 32. - P. 69-78.

41. Феоктистов А.В., Феоктистов В.А. Зачем нужен супервайзер? // Недра Поволжья и Прикаспия. - 2010. - Вып. 62. - С. 67-75.

42. Особенности геологоразведочных работ в районах с высокой освоенностью недр (на примере Республики Татарстан) / Р.С. Хисамов, Н.С. Гатиятуллин, Е.А. Тарасов, В.Б. Либерман // Георесурсы. 2008. - Вып. 27. - С. 26-28.

43. Bagaini C., Barajas Olalde C. Assessment and compensation of inconsistent coupling conditions in point receiver land seismic data // Geophysical Prospecting. - 2007. - Vol. 55, iss. 1.

44. Михеев С.И., Селезнёв В.А., Зуб Е.А. Новые Технико-методические приёмы полевых сейсморазведочных работ // Недра Поволжья и Прикаспия. - 2014. - Вып. 79. - С. 30-39.

45. Кострыгин Ю.П., Кострыгина А.А. Группирование сейсмоприёмников и сейсмических излучателей: учеб. пособие; Изд-во Кубан. гос. ун-та. - Краснодар, 2018. - С. 58.

Please cite this article in English as:

Zakharov Iu.M., Putilov I.S. Obtaining high-quality seismic data in the wetlands in the North of Perm Krai. Perm Journal of Petroleum and Mining Engineering, 2020, vol.20, no.2, pp.115-125. DOI: 10.15593/2224-9923/2020.2.2

Просьба ссылаться на эту статью в русскоязычных источниках следующим образом:

Захаров Ю.М., Путилов И.С. Получение качественных сейсмических данных на заболоченных территориях севера Пермского края // Вестник Пермского национального исследовательского политехнического университета. Геология. Нефтегазовое и горное дело. - 2020. - Т.20, №2. - С.115-125. DOI: 10.15593/2224-9923/2020.2.2 